\title{
Rehberlik ve Psikolojik Danışmanlık Programı Öğrencilerinin Özel Ĕ̆itimde Öz-Yeterlik Algıları
}

\section{School Counselor Candidates' Perceptions of Self-Efficacy in Special Education}

\author{
Nesrin SÖNMEZ*, Melike KOÇYIĞIT ${ }^{* *}$, Ömür GÜREL SELIMOĞLU***
}

•GelişTarihi:10.07.2019 •KabulTarihi:13.12.2019 •Çevrimiçi YayınTarihi:13.12.2019

\begin{abstract}
$\ddot{\mathbf{O z}}$
Türkiye'de üniversitelerin rehberlik ve psikolojik danışmanlık (RPD) programı mezunları eğitim kurumlarında çalıştıklarında "rehber öğretmen" kadrosunda görev yapmaktadır. Rehber öğretmenler eğitim kurumlarında gelişimi olağan seyreden öğrencilerle yürüttükleri psikolojik danışma ve rehberlik (PDR) uygulamaları yanında, okuldaki özel gereksinimli öğrencilere, öğretmenlerine ve ailelerine yönelik olarak da önemli görevler yürütmektedir. RPD programında öğrenim gören öğrencilerin özel eğitimde PDR hizmetlerine ilişkin öz-yeterlik algılarını belirlemek üzere yürütülen bu çalışmada, öğrencilerin öz-yeterlik algıları çeşitli değişkenler açısından incelenmiştir. Betimsel tarama modeli ile gerçekleştirilen çalışmanın katılımcıları iki üniversitenin RPD programında öğrenim gören ve çalışmaya katılmaya gönüllü olan 243 öğrencidir. Çalışmada veri toplama aracı olarak kişisel bilgi formu ve Rehber Öğretmen Özel Eğitim Öz-Yeterlik Ölçeği (RÖ-ÖEÖYÖ) kullanılmıştır. Veriler SPSS 20 paket programı aracılığıyla analiz edilmiş, analizler için bağımsız gruplar için t testi ve ANOVA kullanılmıştır. Çalışma sonunda, RPD öğrencilerinin özel eğitim öz-yeterlik algıları orta düzey olarak belirlenmiştir. Öğrencilerin özel eğitim öz-yeterlik algıları cinsiyet, alınan dersler ve özel gereksinimli birey(ler)le etkileşimde bulunma süresi açısından farklılaşmazken, sınıf düzeyi ve ileride özel eğitimle ilgili bir kurumda çalışma isteğine göre anlamlı düzeyde farklılaşmıştır.
\end{abstract}

Anahtar Kelimeler: rehberlik ve psikolojik danışma; özel eğitim; öz-yeterlik algısı

Atıf:

Sönmez, N., Koçyiğit, M., ve Gürel Selimoğlu, Ö. (2020). Rehberlik ve psikolojik danışmanlık programı öğrencilerinin özel eğitimde öz-yeterlik algıları. Pamukkale Üniversitesi Eğitim Fakültesi Dergisi, 49, 484-505. doi: 10.9779/pauefd.589837.

* Dr. Öğr. Üyesi, Akdeniz Üni. Eğitim F. Özel Eğitim Böl., ndilersonmez@gmail.com, https://orcid.org/0000-00022497-2336

Dr., Akdeniz Üni. Eğitim F. Eğitim Bil. Böl., Rehberlik ve Psk. Dan. ABD, mkocyigit@akdeniz.edu.tr, https://orcid.org/0000-0002-1446-9761

Dr. Öğr. Üyesi, Akdeniz Üni. Eğitim F. Özel Eğitim Böl., omur-gurel@,hotmail.com, https://orcid.org/0000-0003$\underline{3212-713 X}$ 


\title{
Rehberlik ve Psikolojik Danışmanlık Programı Öğrencilerinin Özel Eğitimde Öz-Yeterlik Algıları
}

\begin{abstract}
Students who graduated from the guidance and counseling program $(\mathrm{GaCP})$ of the universities in Turkey serves as "school counselor" in educational institutions. School counselors working in educational institutions carry out important tasks for the students with special needs, teachers and their families in the school as well as counseling and guidance services (CaGSs) with the students whose development is normal. In this study conducted to determine the school counselor candidates' perceptions of self-efficacy regarding CaGSs in special education, self-efficacy perceptions of the school counselor candidates in special education were examined in terms of various variables. The survey model consisted of 243 participants who were volunteers to participate in the GaCP of two universities. Personal information form and School Counselors' Self-Efficacy Scale regarding Special Education (SCSSSE) were used as data collection tool. Data analysis was analyzed by SPSS 20 package program and t-test for independent groups and ANOVA were used for analysis. At the end of the study, school counselor candidates' perceptions of selfefficacy in special education were determined as medium level. Candidates' self-efficacy perceptions in special education did not differ in terms of gender, lessons learned and duration of interaction with the individual(s) with special needs, but significantly differed according to class level and the desire to work in an institution related to special education in the future.
\end{abstract}

Keywords: guidance and counseling; special education; self-efficacy perception

\section{Cited:}

Sönmez, N., Koçyiğit, M., \& Gürel Selimoğlu, Ö. (2020). School counselor candidates’ perceptions of self-efficacy in special education. Pamukkale Üniversitesi Ĕgitim Fakültesi Dergisi, 49, 484-505. doi: 10.9779/pauefd.589837. 


\section{Giriş}

Türkiye'de üniversitelerin rehberlik ve psikolojik danışma (RPD) programından mezun olan öğrenciler eğitim kurumlarında çalıştıklarında "rehber öğretmen" kadrosunda görev yapmaktadır. Okul ve kurumlarda görevli rehber öğretmenler, bireylere kendini tanıma, karar verme ve problem çözme becerileri kazandıran, bireylerin kişisel ve toplumsal uyumlarını gerçekleştirmelerini sağlamak amacıyla psikolojik danışma ve rehberlik (PDR) süreçlerini yürüten kişilerdir (Hott, Thomas, Abbassi, Hendricks ve Aslina, 2015; Kaygusuz, 2014). Rehber öğretmenler tüm öğrencilerin eğitim yaşamında son derece önemli bir role sahiptir (Oberman ve Graham, 2016). Rehber öğretmenler görev yaptıkları eğitim kurumlarında, psikolojik danışma hizmetleri, oryantasyon hizmetleri, öğrenciyi tanıma hizmetleri gibi öğrenciye dönük hizmetler yanında okul PDR programı hazırlama, danışma hizmetleri, anababalara rehberlik hizmetleri gibi dolaylı hizmetler de sunmaktadır (Güven, 2014).

Genel eğitim okullarında görevli rehber öğretmenler, gelişimi olağan seyreden öğrencilerle PDR uygulamaları yanında okuldaki kaynaştırma öğrencilerine, öğretmenlerine ve ailelerine yönelik olarak da önemli görevler yürütmektedir. Bu görevler arasında, öğrenciyi tanı için yönlendirme, bireyselleştirilmiş eğitim programı (BEP) hazırlama, özel yetenekli öğrenciler için zenginleştirme programı hazırlama, gelişim takibi, aile eğitimi, sınıf içi davranış sorunları, sosyal kabulü sağlamaya yönelik etkinlikleri planlama ve uygulama sayılabilir (Nichter ve Edmonson, 2005). Rehber öğretmenler kaynaştırma eğitimi veren okulda bulunması zorunlu olan "BEP Biriminde" görevlidir ve sayılan bu görevlerin yerine getirilmesinde BEP Birimi üyeleriyle birlikte çalışmaktadır (Milli Eğitim Bakanlığı, 2018a).

Rehber öğretmenlerin görev alanları genel eğitim okullarında kaynaştırma öğrencisi olan ve olmayan öğrencilere ve ailelerine verdikleri PDR hizmetiyle de sınırlı değildir. Özel eğitim hizmeti veren çeşitli kurum ve kuruluşlarda da önemli görevler yürütmektedir. Resmi veya özel özel eğitim kurumları ya da Rehberlik ve Araştırma Merkezi'nde (RAM) oluşturulan özel eğitimle ilgili çeşitli kurullarda görev yapmaktadır. Bu kurullardan il milli eğitim müdürlükleri ve RAM bulunan ilçe milli eğitim müdürlüklerindeki "Özel Eğitim Hizmetleri Kurulunda”, özel gereksinimli öğrenci (ÖGÖ) ile ilgili eğitsel kararların alınmasında kurulun doğal üyesi olarak görev yapmaktadır. Rehber öğretmenler, RAM'larda oluşturulan "Özel Eğitim Değerlendirme Kurulunda" da bulunması zorunlu personeldir ve kurulun doğal üyesi olarak diğer üyelerle birlikte, eğitsel tanılama ve değerlendirme, yönlendirme ve izleme çalışmaları ile aile eğitimi çalışmalarında görev almaktadır. Rehber öğretmenler özel eğitim okullarında da görev alabilmektedir. Farklı yetersizlik gruplarına göre ayrı eğitim ortamı olarak hizmet veren bu okullarda BEP Biriminde görev almakta ve de kendisinden okuldaki tüm ÖGÖ’lerin ve velilerinin ihtiyaçlarına göre gerekli PDR süreçlerini yürütmesi beklenmektedir.

Türkiye'de, özel eğitim hizmetlerinin yaygınlaşması ile birlikte özel eğitim hizmetlerinden yararlanan öğrenci sayılarında ciddi artış olmuştur. Genel eğitim ortamlarında öğrenim gören kaynaştırma öğrencilerinin sayıların yayınlandığı Milli Eğitim Bakanlığı (MEB) 2017-2018 verilerine göre, örgün eğitimde toplam 257.770 kaynaştırma öğrencisi bulunmaktadır. 2009-2010 verilerinde ise bu sayı toplam 76.204'tür. Yani son 8 yılda örgün eğitimde kaynaştırma öğrencisinin artış oranı \%238,26'dır. Yine 2009-2010'da ayrı eğitim kurumlarında öğrenim gören özel gereksinimli öğrenci sayıs1 61.801 iken, 2017-2018'de bu say1 139.759'a ulaşmış ve artış oranı \%126 olmuştur (MEB, 2018b). Dolayısıyla eğitim sisteminde 
yer alan kurumların ve aktörlerin, öğrenim görmekte olan ÖGÖ sayısının bu hızlı artışına cevap verebilmesi oldukça güç olmakta ve bunun sonucunda da süreçte çeşitli sorunlarla karşılaşılması kaçınılmaz olmaktadır.

Özel eğitim hizmetlerinin sunulduğu tüm kurum ve kuruluşlarda sağlanan özel eğitim ve destek hizmetlerinin yürütülmesinde karşılaşılan sorunların çözümünde ilk başvurulan meslek elemanı, rehber öğretmenler olmaktadır. Ancak yapılan çalışmalar, rehber öğretmenlerin bu sorunların çözümünde, lisans eğitimleri sırasında, yeterli düzeyde özel eğitim alanı ile ilgili ders alamamalarından ve uygulama yapamamalarından dolayı yetersiz kalabildiklerini ortaya koymaktadır. Rehber öğretmenler yapılan pek çok çalışmada, özel eğitim hizmetlerinin sunulmasına yönelik görevlerini yerine getirme konusunda kendilerini yetersiz gördüklerini, bilgi eksikleri olduğunu ifade etmektedir (Akalın, 2014; Altun, 2015; Arşit, 2019; Cimşir ve Carney, 2016; Güven ve Uyanık Balat, 2006; Özengi, 2009; Sakız ve diğ., 2015; Sargın ve Hamurcu, 2010; Sütçü, 2007).

Türkiye'de üniversitelerin RPD programları incelendiğinde, 2018 y1lında Yüksek Öğretim Kurumu (YÖK) tarafından programda değişiklik yapıldığı; bu yeni programda seçmeli dersler arasında özel eğitim alanı ile ilgili derslerin sayısının eskisine oranla artırıldığı görülmektedir (YÖK, 2018). Ancak bu değişiklik öncesinde uygulanmakta olan RPD programına bakıldığında, özel eğitim alanıyla ilgili zorunlu ders olarak özel eğitim ve öğrenme güçlükleri derslerinin; seçmeli ders olarak ise üniversiteden üniversiteye değişmekle birlikte, kaynaştırma, özel eğitimde PDR hizmetleri derslerinin yer aldığ 1 görülmektedir. Eski ve yeni programdaki uygulamaya dönük dersler arasında ise özel eğitimle ilgili uygulamalı derslere rastlanmamaktadır. Dolayısıyla özel eğitim hizmetlerine yönelik az sayıda ders almış olmak ve deneyim sahibi olamamaktan kaynaklanan donanım eksikliğinin, bu programı bitirerek özel eğitim kurum ve kuruluşlarında görevli rehber öğretmenlerin, kendilerini özel eğitim alanında yetersiz bulmalarında önemli bir etken olabileceği düşünülmektedir.

Bireylerin bir işi icra ederken yaşadıkları olumsuz deneyimler, o işi yapabileceğine dair inançlarını yani öz-yeterlik algılarını zayıflatabilmektedir (Bandura, 2009). Öz-yeterlik algısı düşük bireyler, o işi yapma konusunda daha isteksiz olabilmekte, güç gelen işlerden kaçınabilmekte, tükenmişlik ya da başarısızlık duygularıyla baş edemeyip çabuk pes etmekte, bu da kendilerini daha da yetersiz hissetmelerine yol açarak kişileri bir kısır döngüye sokmaktadır (Tschannen-Moran ve Hoy, 2001). Öte yandan yapılan deneysel çalışmalarda bir kişinin bir işi yapabileceğine dair inancının, motivasyonuna ve yaptığı işe son derece olumlu bir şekilde katkıda bulunduğu gösterilmiştir (Akt. Bandura, 2009; Bandura ve Locke, 2003). Dolayısıyla öz-yeterliğin bireylerin davranışları, becerileri, hareketleri, düşünce örüntüleri ve stres düzeyleri üzerinde etkisi olduğu açıkça görülmektedir (Bandura, 1989).

Rehber öğretmenlerin özel eğitim hizmetlerinde daha yetkin bir şekilde hizmet sunabilmesi için gerekli becerilere, tutumlara, davranış biçimlerine sahip olabilmesinde özyeterlik algılarının etkisinin olduğu yapılan çalışmalarda görülmektedir. Özel eğitimde özyeterlik algıları düşük olan rehber öğretmenlerin, özel gereksinimli bireylere yönelik tutumlarının da düşük olduğu (Kıran ve Dengiz, 2019); özel eğitime ilişkin öz-yeterlik algıs1 düşük olan rehber öğretmenlerin mesleki tükenmişlik düzeylerinin arttığı (Kumcağız, Demir ve Karadaş, 2017) ifade edilmektedir. Bu durumda, rehber öğretmenlerin özel eğitimde PDR hizmetlerine yönelik öz-yeterlik algı düzeylerinin, özel eğitim hizmetlerindeki rollerini yeterli 
seviyede yerine getirmede önemli bir etken olduğu söylenebilir. Bu açıdan bakıldığında rehber öğretmenlerin özel eğitimde PDR hizmetlerine yönelik öz-yeterlik algılarının belirlenmesi önem kazanmaktadır.

Yurtdışı alanyazında daha çok psikolojik danışmanların danışman öz-yeterlik algıları üzerinde duran çalışmalar yapıldığı (örn. Daniels ve Larson, 2001; Johnson, Baker, Kopala, Kiselica ve Thompson, 1989; Urbani, Smith, Maddux, Smaby, Torres-Rivera ve Crews, 2002); Türkiye'de ise bu tür psikolojik danışman öz-yeterliği çalışmaları (örn. Balcı, 2017; Gündüz ve Çelikkaleli, 2009) yanında, özel eğitimde PDR hizmetlerine yönelik öz-yeterlik algılarını inceleyen çalışmaların da yapıldığı görülmektedir. Bu çalışmalarda, rehber öğretmenlerin/RPD programı öğrencilerinin özel eğitimde öz-yeterlik algılarının, yüksek (Ateş, 2017; Özdemir, 2018); orta (Aksoy ve Diken, 2009; Cimşir ve Carney, 2016; Deniz, 2016; Kıran ve Dengiz, 2019; Y1lmaz Bingöl, 2018); orta düzeyin biraz altında (Yüksel, Diken, Aksoy ve Karaaslan, 2012) ve yetersiz (Haksız ve Sakall1-Demirok, 2016) bulunduğu rapor edilmektedir. Bu çalışmalarda, rehber öğretmenlerin ve RPD programı öğrencilerinin, özel eğitimde PDR hizmetleri öz-yeterlik algılarının, yaş, cinsiyet, kıdem, mezun olunan bölüm, engelli yakını olma gibi çeşitli değişkenler açısından da incelendiği görülmektedir.

Yapılan çalışmaların incelenen değişkenler açısından sonuçlarına bakıldığında, bir çalışma dişında (Yüksel ve diğ., 2012)tümünde hem rehber öğretmenlerin hem de RPD programı öğrencilerinin özel eğitimde PDR hizmetlerine yönelik öz-yeterlik algıları ile cinsiyetleri arasında anlamlı fark bulunmadığı görülmektedir. Yaş değişkenini inceleyen iki çalışmanın birinde öğrencilerin yaşları açısından anlamlı fark bulunurken (Yılmaz Bingöl, 2018) rehber öğretmenlerle yapılan diğer çalışmada yaş açısından anlamlı fark olmadığı sonucu elde edilmiştir (Aksoy ve Diken, 2009). Okul ve kurumlarda çalışmakta olan rehber öğretmenlerin mesleki deneyim sürelerini (kıdemi) inceleyen çalışmaların ikisinde anlamlı farklılık bulunurken (Aksoy ve Diken, 2009; Gürbüz ve Bozgeyikli, 2014); diğer ikisinde kıdem açısından anlamlı fark bulunmamıştır (Arşit, 2019; Kola, 2012). Bu çalışmalarda, incelenen özel eğitim deneyimleri, aldıkları uzman desteği, ailesinde engelli birey olma durumu ve bir çalışma hariç (Kola, 2012) mezun olunan program değişkenleri açısından anlamlı ilişki olduğu sonucuna ulaşılmıştır. RPD programı öğrencilerinin özel eğitimde PDR hizmetlerine yönelik öz-yeterlik algılarını inceleyen 4 çalışmada yaş, cinsiyet vb. değişkenlere ek olarak sınıf düzeyi, öğrenim gördüğü üniversite gibi farklı değişkenler de incelenmiştir. Bu çalışmalardan sınıf düzeyi açısından özel eğitimde öz-yeterlik algısını inceleyen üç çalışmada da anlamlı fark olduğu sonucu elde edilmiştir (Yüksel ve diğ., 2012; Y1lmaz Bingöl, 2018; Deniz, 2016). Özdemir, (2018), bu çalışmalardan farklı olarak engelli yakını olma durumunu incelemiş ve anlamlı farklılık bulmamıştır. Aynı çalışmada öğrenim görülen üniversite açısından ise anlamlı fark olduğu sonucu elde edilmiştir.

Yurtdışı alanyazında rehber öğretmenlerin RPD programı öğrencilerinin özel eğitimde PDR hizmetlerine yönelik öz-yeterlik algılarını inceleyen çalışmaya rastlanmamıştır. Bu konuda Türkiye'de yapılan çalışmalara rastlanmış ve bu çalışmaların büyük kısmının eğitim kurumlarında görevli rehber öğretmenlerle yapıldığı, hizmet öncesinde öğrencilerle yapılan sınırlı sayıda çalışma olduğu görülmüştür. RPD programından mezun olan öğrenciler çok farklı iş kollarında farklı kadrolarda çalışabilmekle birlikte en fazla sayıda ihtiyaç ve kadrolaşma MEB'e bağlı kurum ve kuruluşlarda 'rehber öğretmen' kadrosunda olmaktadır. MEB'e bağlı 
kurum ve kuruluşlarda çalışan rehber öğretmenlerin iş yükünün büyük kısmını özel eğitimde PDR süreçleri aldığı düşünüldüğünde, hizmet öncesinde onları, MEB'e bağlı kurum ve kuruluşlarda onlardan beklenen bu süreçleri yerine getirebilecek şekilde yetiştirmek önem kazanmaktadır. Bireylerin aldıkları eğitimin mesleki öz-yeterlik algılarını etkileyen önemli bir etken olduğu düşünüldügünde, RPD programı öğrencilerinin özel eğitimde PDR hizmetleri sunma konusunda kendilerini ne düzeyde yeterli gördüklerini belirlemeye ihtiyaç vardır. Öğrencilerin özel eğitimde PDR hizmetlerine yönelik öz-yeterlik algılarının belirlenmesinin, onlara verilen eğitimin değerlendirilmesine katkı sunacağı, bu yolla müfredat geliştirme çalışmalarına yön verebilecek veriler sunacağı, programa özel eğitimde yeterliklerini geliştirmeyi sağlayacak daha fazla ders ve uygulamanın konulmasını sağlayacak adımların atılmasında katkı sağlayacağı beklenmektedir.

Rehber öğretmenlerin ve RPD programı öğrencilerinin özel eğitimde PDR hizmetlerine yönelik öz-yeterlik algısını belirlemeye yönelik önceki çalışmalarda genellikle, cinsiyet, yaş, sınıf düzeyi, kıdem gibi değişkenlerin ele alındığı görülmektedir. Halbuki konu ile ilgili pek çok çalışmada en fazla dile getirilen sorunlardan biri olarak hizmet öncesinde RPD programı öğrencilerinin özel eğitim alanı ilgili aldıkları derslerin azlığı ifade edilmektedir (Akalın, 2014; Cimşir, 2019; Cimşir ve Carney, 2016; Güçyeter, 2018; Güven ve Uyanık Balat, 2006; Haksız ve Sakallı-Demirok, 2017; Özengi, 2009; Sakız ve diğ., 2015; Sargın ve Hamurcu, 2010; Sütçü, 2007; Vural Batık ve Fırıncı Kodaz, 2018). Dolayısıyla özel eğitim alanında bu kadar önemli rolü olan bir meslek grubunun hizmet öncesinde özel eğitim alanıyla ilgili aldı ̆̆ derslerin özel eğitimde PDR hizmetlerine yönelik öz-yeterlik algısını etkileyen bir değişken olup olmadığının sınanmasının yararlı olacağı düşünülmektedir. Yine, önceki çalışmalarda çok ele alınmayan özel gereksinimli bireylerle etkileşim süresi, mezun olduktan sonra özel eğitim hizmeti veren kurum ya da kuruluşlarda çalışma isteğinde olup olmaması değişkenlerinin de sınanmasının alana katk1 sağlayacağı düşünülmektedir. Bu tür değişkenlerin etkisinin sınanmasıyla elde edilen verilerin, RPD öğrencilerinin özel eğitimde PDR hizmetlerine ilişkin öz-yeterlik algısını artırmaya yönelik yapılacak çalışmalara yön vermesi umulmaktadır. Ayrıca, bu çalışmada rehber öğretmenlerle yapılan önceki araştırmalarda incelenen ve farklı sonuçlar elde edilen cinsiyet ve sınıf seviyesi değişkenleri, farklı örneklem üzerinde test edilerek, elde edilen sonuçların diğer çalışma sonuçlarıyla birlikte tartışlabilmesi ve böylece alanyazına katkı sunması beklenmektedir.

Sonuçta bu çalışmada, RPD programı öğrencilerinin, özel eğitimde PDR hizmetlerine yönelik öz-yeterlik algılarını ve bu algılarını etkileyen değişkenleri belirlemek amaçlanmış ve bu amaca yönelik olarak aşağıdaki sorulara yanıt aranmıştır:

1. RPD programı öğrencilerinin, özel eğitimde PDR hizmetlerine yönelik öz-yeterlik algıları ne düzeydedir?

2. RPD programı öğrencilerinin, özel eğitimde PDR hizmetlerine yönelik öz-yeterlik algiları,

a. Cinsiyete,

b. Sinıf seviyesine,

c. Özel eğitimle ilgili alınan derslere,

d. Özel gereksinimli birey(ler)le etkileşimde bulunma süresine, 
e. Mezun olduktan sonra özel eğitim hizmeti veren kurum ya da kuruluşlarda (Rehberlik ve Araştırma Merkezi, resmi veya özel özel eğitim kurumları) çalışmak isteyip istememeye göre anlamlı ölçüde farklılaşmakta mıdır?

\section{Yöntem}

\section{Araștırmanın Modeli}

RPD programı öğrencilerinin özel eğitimde PDR hizmetlerine yönelik öz-yeterlik düzeylerini belirlemek ve cinsiyet, sınıf düzeyi, özel eğitimle ilgili alınan dersler gibi değişkenlere göre katılımcıların özel eğitimde öz-yeterlik algılarının farklılaşıp farklılaşmadığını ortaya koymak amacıyla yürütülen bu araştırma bir betimsel tarama araştırmasıdır. Fraenkel, Wallen ve Hyun'a (2012) göre betimsel tarama araştırmaları, belirli bir grubun ya da bireylerin özelliklerini, tercihlerini ve davranışlarını ortaya koymayı amaçlamaktadır.

\section{Çalışma Grubu}

Araştırmanın çalışma grubu, kolay ulaşılabilir örnekleme kullanılarak Ege Üniversitesi ve Akdeniz Üniversitesi'nin eğitim fakültesi RPD lisans programında 2., 3. ve 4. sınıfta öğrenim gören 243 öğrenciden oluşmaktadır.

Tablo 1. Katılımcıların Değişkenlere İlişkin Betimsel İstatistikleri

\begin{tabular}{|c|c|c|c|c|}
\hline Cinsiyet & $\mathrm{N}$ & $\%$ & $\mathrm{X}_{\mathrm{ort}}$ & Ss \\
\hline Kadın & 174 & 71.6 & 130.71 & 20.11 \\
\hline Erkek & 69 & 28.4 & 134.36 & 19.60 \\
\hline Toplam & 243 & 100 & & \\
\hline \multicolumn{5}{|l|}{ Sınıf Düzeyi } \\
\hline 2.Sinif & 58 & 23.9 & 138.44 & 17,26 \\
\hline 3.Sinıf & 89 & 36.6 & 127.97 & 20,61 \\
\hline 4.Sinif & 96 & 39.5 & 131.21 & 20,13 \\
\hline Toplam & 243 & 100 & & \\
\hline \multicolumn{5}{|l|}{ Alınan dersler } \\
\hline Öğrenme Güçlüğü Dersini alanlar & 122 & 50.2 & 130.86 & 19,26 \\
\hline Öğrenme Güçlüğü Dersini almayanlar & 120 & 49.4 & 132.70 & 20,83 \\
\hline Kayıp Veri & 1 & 0.4 & & \\
\hline Kaynaştırma dersini alanlar & 25 & 10.3 & 141.85 & 22.14 \\
\hline Kaynaştırma dersini almayanlar & 218 & 89.7 & 130.59 & 19.45 \\
\hline Toplam & 243 & 100 & & \\
\hline \multicolumn{5}{|l|}{ Özel Eğitim Kurumunda Çalışma İsteği } \\
\hline $\begin{array}{l}\text { Özel Eğitim Hizmeti veren kurumda } \\
\text { çalışmak isteyenler }\end{array}$ & 178 & 73.3 & 134.71 & 19,27 \\
\hline $\begin{array}{l}\text { Özel Eğitim Hizmeti veren kurumda } \\
\text { çalışmak istemeyenler }\end{array}$ & 65 & 26.6 & 123.59 & 19,97 \\
\hline Toplam & 243 & 100 & & \\
\hline \multicolumn{5}{|c|}{$\begin{array}{l}\text { Ozel Gereksinimli Bireylerle Etkileşimde } \\
\text { Bulunma Süresi }\end{array}$} \\
\hline Hiç & 2 & 0.9 & 139.5 & 7.77 \\
\hline 1aydan az & 168 & 69.1 & 130.58 & 19.05 \\
\hline 1-3ay & 23 & 9.5 & 136.88 & 14.98 \\
\hline
\end{tabular}




\begin{tabular}{lcccc}
\hline 3-6ay & 13 & 5.3 & 139 & 24.27 \\
6 aydan fazla & 37 & 15.2 & 130.87 & 24.95 \\
Toplam & 243 & 100 & & \\
\hline
\end{tabular}

Tablo 1'e göre katılımcıların, \%71,6's1 kadın, \%28,4'u erkektir (Kadın=174, Erkek=69). Katılımcıların \%23,9'u ikinci sınıf, \% 36,6'sı üçüncü sınıf, \%39,5’u dördüncü sınıf öğrencisidir. Çalışma grubunu tanımlamak amacıyla katılımcılardan alınan diğer bilgilere göre yaşları 19-46 $\left(\mathrm{X}_{\text {ort }}=21,6\right)$ arasında değişen katılımcıların neredeyse tümü özel eğitim dersi almıştır $(\mathrm{N}=240)$. Yaklaşık yarısı öğrenme güçlüğü dersi almış $(\mathrm{N}=122)$, kaynaştırma dersini alanların sayısı ise 25 olup, en az bu dersin alındığı görülmektedir. Katılımcıların \%73,3 $(\mathrm{N}=178)$ mezun olduktan sonra özel eğitim hizmeti veren kurum ve kuruluşlarda çalışmak istediğini, \%26,6'sı ( $\mathrm{N}=65)$ ise çalışmak istemediğini belirtmiştir. Ayrıca katılımcıların \%69,1'i özel gereksinimli bireylerle etkileşimde bulunma süresini 1 aydan az olarak belirtmiştir. Hiç etkileşime girmeyen ise iki kişi bulunmaktadır.

\section{Verilerin Toplanması}

Veriler 2017-2018 eğitim öğretim yılı bahar yarıyılında, Şubat ve Nisan ayları arasında Ege Üniversitesi ve Akdeniz Üniversitesi'nde toplanmıştır. Verilerin toplanmasında, özel eğitimle ilgili ders almış olmaları sebebiyle ikinci sınıftan itibaren öğrenciler araştırmaya dahil edilmiştir. Veriler ilgili anabilim dallarında ders veren öğretim üyeleriyle temasa geçilmiş, araştırma hakkında kısa bilgi sunulmuş, uygun görmeleri durumunda belirtilen ders günü ders saatinden 10 dakika önce sınıfa giderek ölçekler uygulanmıştır. Katılımcılara çalışmanın amacı ve ölçek hakkında bilgi verilmiş, çalışmaya gönüllü olmaları durumunda bilime sunacakları katkılar açıklanmıştır. Doldurmak zorunda olmadıkları, doldurmayanların herhangi bir not vs. kaygısının olamaması gerektiği yönünde açıklamalar yapılmıştır. Gönüllü olmayan olup olmadığı sorulmuştur. Çalışmada o gün derste hazır bulunan tüm öğrenciler ölçek maddelerini uygulamayı kabul etmiştir. Ziyaret edilen sınıflarda öğrencilerin büyük kısmının ilgili derste hazır olmasından dolayı örneklemin tamamına yakınına ulaşıldığı belirlenmiştir. Öğrencilere ölçeği doldururken kimlik bilgisi alınmayacağ 1 bu nedenle olabildiğince samimi şekilde cevaplamaları beklendiği yönünde açıklamalar yapılmıştır. Bilgi formu ve ölçeğin nasıl doldurulacağı da açıklanmıştır. Olabildiğince sessiz olmaları soruları olursa yalnızca araştırmacıya sormaları gerektiği, kendi aralarında konuşmamaları yönünde telkinlerde bulunulmuştur.Yalnızca bir öğrenci alınan dersler değişkeninde aldığı dersleri işaretlemediği görülmüştür. Bunun dışında tüm katılımcıların bilgi formu ve ölçek maddelerini eksiksiz doldurduğu belirlenmiştir. Ölçeğin uygulanması sırasında yeterli sayıda kalem ve silgi temin edilmiştir. Verilerin toplanması yaklaşı $15 \mathrm{dk}$. sürmüştür.

\section{Çalışmada Kullanılan Ölçme Araçları}

Araştırma veri toplama aracı olarak kişisel bilgi formu ve Rehber Öğretmen Özel Eğitim ÖzYeterlik Ölçeği (RÖ-ÖEÖYÖ) kullanılmıştır.

\section{Kişisel bilgi formu}

Araştırmacılar tarafından hazırlanan kişisel bilgi formu, cinsiyet, yaş, sınıf düzeyi, özel eğitimle ilgili aldıkları dersler, özel eğitime gereksinim duyan bireylerle etkileşime geçme süresi ve mezun olduktan sonra özel eğitim kurumlarında çalışmayı isteme durumu değişkenlerine ait bilgileri edinmeyi amaçlayan soruları içermektedir. 


\section{Rehber öğretmen özel ĕgitim öz-yeterlik ölçeği (RÖ-ÖEÖYÖ)}

Beşli Likert tipinde hazırlanmış, 40 maddeden oluşan RÖ-ÖEÖYÖ, Aksoy ve Diken (2009) tarafindan geliştirilmiştir. Ölçek tek boyutlu olup, ölçekten alınabilecek en düşük puan 40, en yüksek puan 200'dür. Puanın yüksek olması, rehber öğretmenlerin özel eğitimde PDR hizmetlerine ilişkin öz-yeterlik algılarının yüksek olduğuna işaret etmektedir. Ölçeğin geliştirilmesinde, rehber öğretmenlerden elde edilen verilerin kullanıldığı görülmektedir. Söz konusu çalışmada, Cronbach Alfa iç tutarlık katsayısı .98, test-tekrar test güvenirlik katsayısı .96 olarak belirtilmiştir. Ölçeğin RPD programı öğrencilerinden oluşan başka bir örneklemde de geçerli olup olmadığ 1 test edilmiş ve iç tutarlık katsayısı .97 ve test-tekrar test güvenirlik katsayıs1 .98 olarak hesaplanmıştır (Yüksel ve diğ., 2012). Bu araştırma için ölçeğin Cronbach Alfa iç tutarlık katsayısı .94 bulunmuştur.

\section{Verilerin Analizi}

Analizlere başlamadan önce gözlemlerin bağımsızlığı, normal dağılım ve varyansların homojenliği gibi varsayımlar test edilmiştir. Normallik testi sonuçları Skewness-Kurtosis değerlerinin $-1,1$ arasında olduğunu göstermiştir. Varyansların homojenliği varsayımının da sağlandığı anlaşıldıktan sonra analizler gerçekleştirilmiştir. Veri analizi SPSS 20 paket programı aracılığıyla yapılmıştır. Verilerin analizinde bağımsız değişkenin grup sayısı göz önünde bulundurularak, gruplar arası ortalamalar farkını ortaya koyabilmek amacıyla bağımsız gruplar için t testi ve tek yönlü ANOVA kullanılmıştır. Öğrencilerin özel eğitimde öz-yeterlik algılarını ortaya koymak için minimum ve maksimum puanlar, ortalama, standart sapma gibi değerlerden de yararlanılmıştır.

\section{Bulgular}

Araştırmada ilk olarak "RPD programı öğrencilerinin özel eğitimde PDR hizmetlerine ilişkin öz-yeterlik algılarının düzeyleri” incelenmiştir. Bu amaca yönelik bulgular Tablo 2'de verilmektedir.

Tablo 2. RPD Programı Öğrencilerinin RÖ-ÖEÖYÖ’den Aldığı Puan Ortalamaları

\begin{tabular}{llllll}
\hline Grup & $\mathrm{N}$ & Min. & Maks. & $\mathrm{X}_{\text {ort }}$ & Ss \\
\hline Toplam & 243 & 76 & 186 & & \\
Alt & 39 & 76 & 112 & & \\
Orta & 169 & 113 & 152 & & 19.99 \\
Üst & 35 & 153 & 186 & 131.75 & \\
\hline
\end{tabular}

Tablo 2 incelendiğinde, katılımcıların RÖ-ÖEÖYÖ'den aldığı puan ortalamasının 131,75 olduğu görülmektedir. Ölçekten en düşük alınan puan 76 iken, en yüksek alınan puan 186'dır. Erkuş'un (2012) "bağıl değerleme" olarak ifade ettiği şekilde, grubun puan ortalamalarına ilişkin hesaplanan z puanları temel alınarak hesaplanan gruplar, 76-112 alt, 113152 orta, 153-186 üst grup şeklindedir. Katılımcıların puan ortalamasının 131,75 olduğu için puanlarının orta düzeyde olduğu görülmektedir.

Çalışmada ikinci olarak, RPD programı öğrencilerinin özel eğitimde PDR hizmetlerine ilişkin öz-yeterlik algılarının cinsiyet, sınıf düzeyi, özel eğitimle ilgili alınan dersler, özel eğitime gereksinim duyan bireylerle etkileşime geçme süresi ve mezun olduktan sonra özel 
eğitim kurumlarında çalışmayı isteme durumları değişkenlerine göre değişip değişmediği incelenmiştir. Bu kısımda sırasıyla bu değişkenlere ilişkin bulgular sunulmaktadır.

RPD programı öğrencilerinin özel eğitimde PDR hizmetlerine ilişkin öz-yeterlik algılarını etkileyen değişkenlerle ilgili ilk olarak cinsiyet açısından farklılaşmaya bakılmıştır. Kadın ve erkeklerin özel eğitimde PDR hizmetlerine yönelik öz-yeterlik puanları arasında anlamlı farklılık olup olmadığı bağımsız gruplar için t testi ile incelenmiştir. Tablo 3 'te cinsiyete göre özel eğitimde öz-yeterlik puanları bağımsız gruplar için t testi sonuçları verilmektedir.

Tablo 3. Cinsiyete Göre Özel Eğitimde Öz-Yeterlik Puanlarına İlişkin Bağımsız Gruplar t Testi Sonuçları

\begin{tabular}{lrccccc}
\hline Cinsiyet & $\mathrm{N}$ & $\mathrm{X}_{\text {ort }}$ & $T$ & $\mathrm{SS}$ & $\mathrm{Sd}$ & $p$ \\
\hline Kadın & 174 & 130.71 & $-1,284$ & 20.11 & 241 & .201 \\
Erkek & 69 & 134.36 & & 19.60 & & \\
\hline$p>.05$ & & & & & &
\end{tabular}

Tablo 3'de görüldüğü gibi kadınların puan ortalamaları erkeklerin puan ortalamalarına göre düşüktür, ancak bu farkl1lık anlamlı değildir $(t(241)=-1,284, p>.05)$.

Çalışmada incelenen bir diğer değişken sınıf düzeyidir. RPD programı öğrencilerinin özel eğitimde PDR hizmetlerine yönelik öz-yeterlik algılarının sınıf düzeyi açısından farklılaşıp farklılaşmadığı tek yönlü ANOVA testi ile incelenmiştir. Sınıf düzeyine göre özel eğitimde özyeterlik puanlarına ilişkin tek yönlü ANOVA sonuçları Tablo 4'te verilmektedir.

Tablo 4. Sınıf Düzeyine Göre Özel Eğitimde Öz-Yeterlik Puanlarına İlişkin Tek Yönlü ANOVA Sonuçları

\begin{tabular}{ccccccc}
\hline $\begin{array}{c}\text { Varyansın } \\
\text { Kaynağ }\end{array}$ & $\begin{array}{c}\text { Kareler } \\
\text { Toplamı }\end{array}$ & Sd & $\begin{array}{c}\text { Kareler } \\
\text { Ortalaması }\end{array}$ & F & $p$ & $\begin{array}{c}\text { Anlamlı } \\
\text { Fark }\end{array}$ \\
\hline Gruplararası & 3895,46 & 2 & 1947,73 & 5,033 & $.007^{*}$ & $2-3$ \\
Gruplariçi & 92884,99 & 240 & 387,02 & & & \\
Toplam & 96780,46 & 242 & 1947,73 & & & \\
\hline$* p<.05$ & & & & &
\end{tabular}

Tablo 4'te görüldüğü üzere, sınıf düzeyine göre RPD programı öğrencilerinin özel eğitimde PDR hizmetlerine yönelik öz-yeterlik algıları arasında anlamlı farklılık bulunmaktadır $[F(2,240)=5,033, p=.007]$. Farkın kaynağını bulmak üzere post hoc testi yapılmıştır. Hangi post hoc testinin kullanılacağını belirlemek için varyansların homojenliği test edilmiştir. Varyansların homojen olduğu [ $p>.05]$ belirlenmiş ve grupların örneklem sayısının eşit olmadığı durumlarda kullanılması önerilen (Kayri, 2009) Scheffe testi yapılmıştır. Sonuçlar, farkın ikinci ve üçüncü sınıf düzeylerindeki katılımcılardan kaynaklandığını ortaya koymuştur. İkinci sınıf öğrencilerinin puan ortalamalarının daha yüksek olduğu görülmüştür.

Araştırmada incelenen sonraki değişken alınan derslere yöneliktir. Adaylara uygulanan bilgi formunda adaylar, özel eğitim, kaynaştırma ve öğrenme güçlüğü derslerini aldıklarını belirtmiştir. Çalışmanın yapıldığı dönem itibarıyla katılımcıların neredeyse tamamı özel eğitim dersini almış olduğunu beyan ettiği için bu ders açısından herhangi bir analiz yapılmamıştır. Kaynaştırma dersini aldığını belirten adayların sayısı ile almayanların sayısı arasındaki farkın analiz yapmayı engelleyecek büyüklükte olduğu görülmüş ve bu nedenle kaynaştırma dersi 
analiz dışında bırakılmıştır. Alınan dersler arasında bir diğer ders olan öğrenme güçlüğü dersini alma durumlarına yönelik olarak toplanan veriler bağımsız gruplar $t$ testi ile analiz edilmiştir. RPD programı öğrencilerinin özel eğitimde öz-yeterlik algılarında bir farklılaşmaya etki edip etmediğini belirlemek üzere yapılan bağımsız gruplar için t testi sonuçları Tablo 5'te verilmektedir.

Tablo 5. Öğrencilerin Öğrenme Güçlüğü Dersi Alıp Almamalarına Göre Özel Eğitimde Öz-Yeterlik Puanlarına İlişkin Bağımsız Gruplar t Testi Sonuçları

\begin{tabular}{lcccccc}
\hline $\begin{array}{l}\text { Öğrenme Güçlüğü } \\
\text { Dersini Alma Durumu }\end{array}$ & $\mathrm{N}$ & $\mathrm{X}_{\text {ort }}$ & $T$ & $\mathrm{SS}$ & $\mathrm{Sd}$ & $p$ \\
\hline Alanlar & 122 & 130,8654 & -.713 & 19,26111 & 240 & .476 \\
Almayanlar & 120 & 132,7049 & & 20,83149 & & \\
\hline$p>.05$ & & & & & &
\end{tabular}

Tablo 5'te görüldüğü üzere, öğrenme güçlüğü dersini alan ve almayan öğrencilerin puan ortalamalarındaki fark anlamlı bulunmamıştır, $t(240)=-, 713, p>.05)$.

Çalışmada incelenen diğer değişken, özel gereksinimli bireylerle etkileşimde bulunma süresidir. Katılımcıların etkileşimde bulunma sürelerine ilişkin toplanan betimsel istatistiklere bakıldığında, katılımcıların 168'inin 1 aydan az etkileşim süresi olduğu, kalan 75 katılımcının hiç, 1-3 ay, 1-6 ay ve 6 aydan fazla şeklinde yapılan gruplara dağıldığ ve bunun da analiz yapmayı imkânsız kıldığg görülmüştür. Bunun üzerine etkileşim süresini iki grupta toplamaya karar verilmiş, 1 aydan az olanlar ve 1 aydan çok olanlar şeklinde iki gruba ayrılarak veriler analiz edilmiştir. Tablo 6'da RPD programı öğrencilerinin özel gereksinimli bireylerle etkileşim sürelerine göre özel eğitimde öz-yeterlik düzeyine ilişkin bağımsız gruplar için t testi sonuçları yer almaktadır.

Tablo 6. Öğrencilerin Özel Gereksinimli Bireylerle Etkileşim Sürelerine Göre Özel Eğitimde Öz-Yeterlik Puanlarına İlişkin Bağımsız Gruplar t Testi Sonuçları

\begin{tabular}{|c|c|c|c|c|c|c|}
\hline $\begin{array}{l}\text { Özel Gereksinimli } \\
\text { Bireylerle Etkileşimde } \\
\text { Bulunma Süresi }\end{array}$ & $\mathrm{N}$ & $X_{\text {ort }}$ & $T$ & SS & $\mathrm{Sd}$ & $p$ \\
\hline 1 aydan az & 170 & 130,6824 & $-1,261$ & 18,97224 & 241 & .209 \\
\hline 1 aydan fazla & 73 & 134,2055 & & 22,14595 & & \\
\hline
\end{tabular}

Tablo 6'ya göre RPD programı öğrencilerinin özel gereksinimli bireylerle etkileşim süreleri 1 aydan az olanlarla 1 aydan çok olan adayların puan ortalamalarındaki fark anlamlı bulunmamıştır $(t(241)=-1,261, p>.05)$.

Çalı̧̧mada son olarak mezun olduktan sonra özel eğitim hizmeti veren kurum ya da kuruluşlarda çalışma isteği değişkeni incelenmiştir. RPD programı öğrencilerinin özel eğitimde öz-yeterlik algılarının, mezun olduktan sonra özel eğitim hizmeti veren kurum ya da kuruluşlarda çalışma isteğine bağlı olarak farklılaşıp farklılaşmadığı bağımsız gruplar için t testi ile analiz edilmiştir. Tablo 7'de analiz sonuçları verilmektedir. 
Tablo 7. Öğrencilerin Özel Eğitim Hizmeti Veren Kurumda Çalışma İsteğine Göre Özel Eğitim Öz-Yeterlik Puanlarına İlişskin Bağımsız Gruplar t Testi Sonuçları

\begin{tabular}{ccccccc}
\hline $\begin{array}{c}\text { Özel eğitim kurumunda } \\
\text { çalışma isteği }\end{array}$ & $\mathrm{N}$ & $\mathrm{X}_{\text {ort }}$ & $t$ & $\mathrm{SS}$ & $\mathrm{Sd}$ & $p$ \\
\hline Evet & 178 & 134,71 & 3,92 & 19,276 & 240 & $.000^{*}$ \\
Hayır & 65 & 123,59 & & 19,976 & & \\
\hline
\end{tabular}

$\overline{p<.01}$

Tablo 7'ye göre, RPD programı öğrencilerinin mezun olduktan sonra özel eğitim hizmeti veren kurum ya da kuruluşlarda çalışmak istediğini belirtenlerin puan ortalamaları daha yüksektir. Puanlar arasındaki farklılık da anlamlı bulunmuştur $(t(240)=3,92, p<.01)$.

\section{Tartışma ve Sonuç}

RPD programı öğrencilerinin, özel eğitimde PDR hizmetlerine ilişkin öz-yeterlik algılarını ve bu algıları etkileyen değişkenleri belirlemek üzere yapılan bu çalışmaya, iki farklı üniversitenin RPD programlarında 2, 3 ve 4. sınıflarda öğrenim gören öğrenciler katılmıştır. Çalışma sonunda elde edilen bulgulara göre RPD programı öğrencilerinin özel eğitim öz-yeterlik algıları orta düzeydedir. RPD programı öğrencilerinin, özel eğitimde PDR hizmetlerine ilişkin öz-yeterlik algıları ile cinsiyet, özel gereksinimli birey(ler)le etkileşimde bulunma süresi ve öğrenme güçlüğü dersini almış olma değişkenleri açısından anlamlı fark bulunmazken, sınıf seviyesi açısından 2. sınıflar lehine, mezun olduktan sonra özel eğitim hizmeti veren kurum ya da kuruluşlarda çalışmak isteyenler lehine anlamlı fark bulunmuştur.

RPD programı öğrencilerinin özel eğitimde PDR hizmetlerinde öz-yeterlik algıları konusunda yapılmış önceki dört çalışmanın ikisinde adayların özel eğitimde öz-yeterlik algıları,bu çalışmadakine benzer şekilde orta düzeyde (Deniz, 2016; Yılmaz Bingöl, 2018)ve orta düzeyin biraz altında (Yüksel ve diğ.,2012) bulunmuştur. Bu sonuçlar, RPD programı öğrencilerinin hizmet öncesi eğitimlerinde öz-yeterlik algılarını artırmaya hizmet edecek bir eğitim almadıklarına dair ipuçları sunması bakımından önemlidir. Özel eğitimde öz-yeterlik algısının tutumları (Kıran ve Dengiz, 2019) ve mesleki tükenmişlik düzeylerini (Kumcă̆ız, Demir ve Karadaş, 2017) etkilediği de göz önünde bulundurulduğunda, RPD program1 öğrencilerine özel eğitimde öz-yeterlik algılarını artırmaya yönelik yeterli eğitim ve deneyim fırsatlarının sağlanmasının önemi görülmektedir.

Çalışmada RPD programı öğrencilerinin özel eğitimde PDR hizmetlerine yönelik özyeterlik algıları cinsiyet değişkenine göre anlamlı bulunmadığına yönelik elde edilen bulgu, Yılmaz Bingöl (2018), Deniz (2016) ve Özdemir'in (2018) RPD programı öğrencileriyle yaptıkları çalışmaların bulgularıyla örtüşmektedir. Rehber öğretmenlerle yürütülen çalışmalarda da cinsiyet açısından anlamlı bir fark olmadığı sonucu elde edilmiştir (Aksoy ve Diken,2009, Arşit,2019; Gürbüz ve Bozgeyikli,2014 ve Kola,2012). Bir çalışmada ise Yüksel ve diğerleri (2012), RPD programı öğrencilerinin özel eğitimde öz-yeterlik algılarının cinsiyet açısından erkek adaylar lehine anlamlı farklılık gösterdiğini ancak etki büyüklüğünün küçük olduğunu bulmuştur. Tüm bu sonuçlardan yola çıkılarak cinsiyetin rehber öğretmenler ve RPD programı öğrencilerinin özel eğitimde öz-yeterlik algılarını etkileyen bir değişken olmadığı söylenebilir. 
Çalışmada RPD programı öğrencilerinin özel eğitimde PDR hizmetlerine ilişkin özyeterlik algıları sınıf seviyesi açısından 2. sınıflar lehine anlamlı bulunmuştur. İkinci sınıfların puan ortalamaları 3. sinıflara göre yüksektir. Bunun nedeni, ikinci sınıftaki katılımcıların özel eğitim dersini o yıl almış olmalarıyla, 3. sınıftakilerin de bu dersi almaları üzerinden zaman geçmiş olmasıyla açıklanabilir. 4. sınıftaki öğrencilerin ortalamaları 3. sınıfa göre bir miktar yükselse de bu artış anlamlı değildir. Çalışmada elde edilen bu sonuçtan farklı olarak önceki çalışmalarda, sınıf düzeyi açısından anlamlı farklılık olduğu, sınıf seviyesi yükseldikçe özel eğitimde öz-yeterlik algılarının arttığı sonucuna ulaşılmıştır (Deniz,2016; Yılmaz Bingöl,2018; Yüksel ve diğ.,2012). Araştırmacılar bu artışın deneyimle ve özel eğitimle ilgili derslerin alınmasıyla mümkün olabileceğini belirtmektedir. Bu çalışmalar incelendiğinde katılımcıların özel eğitimle ilgili ne tür deneyimleri olduğu betimlenmemekte, özel eğitim ve öğrenme güçlükleri derslerini aldıkları belirtilmektedir. Mevcut çalışmadaki adayların,diğerleriyle aynı dersleri almalarına rağmen puan ortalamalarının sınıf seviyesine göre yükselmemiş olmasında,edinilen deneyimlerin etkisi olabilir. Ayrıca katılımcı özellikleri, derslerin içeriği ve veriliş biçimi, ÖGÖ ile etkileşim fırsatları, dersi veren kişilerin niteliği gibi başka etkenler de devreye girmiş olabilir. Dolayısıyla hangi etkenlerin sonucu nasıl etkileyeceğinin incelenmesi için çalışma yapılmasına gereksinim vardır.

Araştırmada, RPD programı öğrencilerinin öğrenme güçlüğü dersini almış olma durumuyla ilgili olarak, öğrenme güçlüğü dersini alanlar ve almayanlar arasında, özel eğitimde PDR hizmetlerine yönelik öz-yeterlik algılarında anlamlı fark bulunmamıştır. ÖGÖ ile ilgili alınan ders(ler)in, özel eğitimde öz-yeterlik algısı ile ilişkisini inceleyen bir başka çalışmaya rastlanmamıştır. Rehber öğretmenlerle yürütülen bir çalışmada, özel eğitim hakkında lisans veya yüksek lisansta verilen eğitimi yeterli bulan katılımcıların, özel eğitimde PDR hizmetlerine yönelik öz-yeterlik algılarının anlamlı düzeyde yüksek olduğu bulunmuştur (Arşit,2019). Ancak çalışmada katılımcıların kuramsal ve/veya uygulamalı hangi dersleri aldıkları belirtilmemiştir. Rehber öğretmenlerin özel eğitim hizmetlerindeki rolü göz önünde bulundurulduğunda, ÖGÖ’nün fark edilmesi, tanılanması, program geliştirilmesi, izleme, aile eğitimi gibi özel eğitimin tüm aşamalarında aktif görev alacak meslek elemanının, bu konularda hizmet öncesinde kuramsal ve uygulamalı eğitimler alması gereği doğmaktadır. Nitekim araştırmada kullanılan RÖ-ÖEÖYÖ’nün tümüyle bu yeterlikleri ifade eden maddeleri içerdiği söylenebilir. Dolayısıyla ögrenme güçlüğü dersinin özel eğitim hizmetlerinde daha özel bir alana özgü bilgileri içeren bir ders olduğu ve bu nedenle de tüm bu yeterlikleri edinme konusunda öğrencilerin kendilerini yeterli hissetmelerinde tek başına anlamlı fark yaratmadığı düşünülebilir. Yine de bu sonuç, tek başına bir ders almanın, öz-yeterlik algısında anlamlı etki yaratmayabileceği o nedenle daha fazla sayıda özel eğitim alanı ilgili kuramsal ve uygulamalı ders açılması gerektiğine de işaret edebilir.

Yapılan çalışmalarda rehber öğretmenlerin kendilerini özel eğitim alanında yetersiz gördükleri, bilgi eksikleri olduğu ve özel eğitim konusunda lisans eğitimlerinde yeterli sayıda eğitim almadıkları ifade edilmektedir. RPD programı ögrencilerinin eğitimleri sırasında özel eğitim ve ÖGÖ ile ilgili daha fazla ders almaları ve uygulama yapmaları gerektiği pek çok çalışmada da dile getirilen bir husus olmuştur (Akalın, 2014; Altun, 2015; Arşit, 2019; Cimşir, 2019; Cimşir ve Carney, 2016; Deck, Scarborough, Sferrazza ve Estill, 1999; Dunn ve Baker, 2002; Güçyeter, 2018; Güven ve Uyanık Balat, 2006; Kıran ve Dengiz, 2019; Kırbıyı, 2011, Oberman ve Graham, 2016; Özengi, 2009; Sakız ve diğ., 2015; Sargın ve Hamurcu, 2010; 
Studer ve Quigney, 2005; Sütçü, 2007). Çalışmayı yürüten araştırmacılardan ikisinin yaptığı bir diğer çalışmada (incelemede) RPD programı öğrencilerinin 4. sınıf ikinci yarıyılda verilen seçmeli “Özel Eğitimde PDR Hizmetleri” dersini alanlarının özel eğitimde öz-yeterlik algılarında, almayanlara göre anlamlı derecede fark oluştuğu bulgusu elde edilmiştir. Milsom (2002) psikolojik danışmanlarla yürüttüğü çalışmada katılımcıların ÖGÖ ile ilgili daha fazla ders alan ve/veya kursa katılanların kendilerini daha hazır hissettiklerini belirtmektedir. Yine Cimşir (2019) yaptığı çalışmada Özel Eğitimde Psikolojik Danışma ve Rehberlik dersinin, RPD programı ögrencilerinin engelli bireylere ilişkin tutumlarında ve hazırlık düzeylerinde anlamlı düzeyde fark oluşturduğunu belirtmekte ve bu sonuçtan hareketle RPD müfredatına daha fazla özel eğitim alanı ile ilgili dersin konmasını önermektedir. Dolayısıyla RPD programı öğrencilerine,onları özel eğitimde PDR hizmetlerine hazırlayacak nitelikte derslerin verilmesi son derece önemli görülmektedir.

2018-2019 eğitim öğretim döneminden itibaren geçerli olmak üzere, Yüksek Öğretim Kurulu (YÖK) tarafından yapılan program değişikliği ile RPD programına seçmeli olarak pek çok özel eğitim alanı ile ilgili ders eklenmiştir (YÖK, 2018). Bu dersler arasında "Kapsayıcı Eğitim", Dikkat Eksikliği ve Hiperaktivite Bozukluğu”, "Öğretimi Bireyselleştirme ve Uyarlama”, "Türk İşaret Dili”, "Özel Yetenekli Çocuklar ve Eğitimi”, "Uygulamalı Davranış Analizi" isimli dersler yer almaktadır. Önceki programda yer alan ve sadece RPD programında 3 kredilik zorunlu bir ders olan "Özel Eğitim" dersinin ise kredisi diğer öğretmenlik programlarında olduğu gibi 2 krediye düşürülmüş ve dersin adı "Özel Eğitim ve Kaynaştırma" olmuştur. Bu dersler,öğrencilerin özel eğitimde öz-yeterliklerini artırmaya hizmet edebilecek nitelikte derslerdir. Ancak, tek başına ders almanın yeterli olamayacağı bu nedenle de kurum deneyiminde de olabildiğince çok sayıda ÖGÖ ve ailesi ile uygulamaların yapılması, özel eğitimde PDR hizmetlerine yönelik hizmet öncesinde RPD programı öğrencilerinin kuramsal ders yanında süpervizörlük süreciyle uygulamalı olarak eğitim verilmesi gerektiğini de vurgulamak yararlı olacaktır.

Araştırmada incelenen bir diğer değişken olan “özel gereksinimli birey(ler)le etkileşimde bulunma süresi” açısından elde edilen sonuçlar, etkileşim süresinin RPD programı öğrencilerinin özel eğitimde öz-yeterlik algılarında anlamlı fark yaratmadığını göstermiştir. Çalışmada etkileşim süresi açısından veriler toplanırken bu etkileşimin türü, niteliği ya da amacı (örn. yakınının ÖGÖ olması, uygulama okullarında ÖGÖ olması) hakkında sorular sorulmamıştır. Dolayısıyla etkileşimin süresi yanında niteliğinin sorgulanması yararlı olabilir. Alan yazında özel gereksinimli bireylerle etkileşimin süresini inceleyen çalışma bulunmamakla birlikte, ailesinde özel gereksinimli birey olmasının özel eğitimde öz-yeterlik algısıyla ilişkisini araştıran iki çalışmada farklı sonuçlar elde edildiği görülmüştür. Özdemir (2018), farklı üniversitelerden RPD programı öğrencileriyle yürüttüğü çalışmasında, engelli yakını olma durumuna göre özel eğitimde öz-yeterlik algılarında anlamlı farklılık bulmamıştır. Rehber öğretmenlerle yapılan diğer çalışmada ise Gürbüz ve Bozgeyikli (2014), ailesinde engelli birey olma durumu açısından anlamlı düzeyde farklılık olduğunu bulmuştur. Dolayısıyla farklı sonuçların elde edilmiş olmasında pek çok etken olabileceğinden bu etkenlerin ileri araştırmalarda sınanması yararlı olabilir.

Çalı̧̧mada incelenen bir diğer değişken "mezun olduktan sonra özel eğitim hizmeti veren kurum ya da kuruluşlarda (RAM, resmi veya özel özel eğitim kurumları) çalışmak isteyip 
istemediğidir”. RPD programı öğrencilerinin özel eğitimde PDR hizmetlerine yönelik özyeterlik puanlarında, ileride özel eğitim kurumlarında çalışmayı isteyenler lehine anlamlı fark bulunmuştur. Bu sonuçtan yola çıkılarak, öğrencilerin ileride bu alanda çalışma konusunda daha istekli olması, onların bu alanda kendilerini yetkin hissetmeleriyle açıklanabilir bir durumdur denilebilir. RPD programı öğrencilerinin ileride özel eğitimde çalışma isteğinin, özel eğitimde öz-yeterlik algılarında fark yaratıp yaratmadığını inceleyen bir çalışmaya rastlanmamıştır. Ancak iki farklı üniversitenin RPD programı 3. sınıf ve 4. sınıf öğrencilerinin kaynaştırmaya yönelik görüşlerinin incelendiği bir çalışmada araştırmacılar, ileride özel eğitim kurumlarında çalışmayı isteyip istememe durumu açısından Kaynaştırmaya Yönelik Görüşler Ölçeğinin bir alt boyutunda (kaynaştırmanın yararları) anlamlı fark bulmuştur (Alver, Bozgeyikli ve Işıklar, 2011). Ölçeğin diğer üç alt boyutunda ve genel ortalamalar açısından ise anlamlı fark bulunmamıştır. Araştırmacıların belirttiği önemli bir husus da katılımcıların \%81,7'sinin özel eğitim kurumlarında çalışmak istemediklerini belirtmiş olmasıdır. Mevcut çalışmada ise katılımcıların \%73,3'ü ileride özel eğitim kurum ya da kuruluşlarında çalışmak istediğini belirtmiştir. Alver ve diğerlerinin (2011) çalışmasında katılımcıların lisans eğitimlerinde aldıkları derslere ilişkin bilgi verilmemekle birlikte çalışmanın yapıldığı tarih itibarıyla RPD programlarında Özel Eğitim, Öğrenme Güçlükleri vb. derslerin yer almadığı, o dönemde bölümlerin programlarına, zorunlu olmamakla birlikte, kendi inisiyatifleri ile bu tür dersleri koydukları bilinmektedir. Sonuçta mevcut araştırmada katılımcıların büyük kısmının ileride özel eğitim kurum ve kuruluşlarında çalışmak istiyor olması ve bunu isteyenlerin puanlarında anlamlı fark olması da günümüz RPD programlarına özel eğitim alanıyla ilgili derslerin eklenmiş olmasıyla açıklanabilir. Ancak daha önce de belirtildiği gibi mevcut derslerin de RPD programı öğrencilerinin özel eğitim öz-yeterlik algılarının yüksek bulunması için yeterli olmadığı, daha fazla ders ve uygulamaya gereksinimleri olduğu açıktır. Bu açıdan bakıldığında bu program değişikliğinden sonra daha çok sayıda özel eğitim alanı ile ilgili ders almaları olası adayların aldıkları derslere göre özel eğitimde öz-yeterlik algılarının farklılaşıp farklılaşmadığının belirlenmesi yararlı olabilir.

Araştırmada elde edilen veriler iki üniversitenin RPD programında öğrenim gören öğrenciler ile ve de veri toplamada kullanılan ölçme araçlarıyla sınırlıdır. Çalışmada RPD programı öğrencilerinin özel eğitimde öz-yeterlik algılarının bir ölçekle ölçülmüş olması, bu amaca yönelik nitel veri toplanmamış olması da bir sınırlılık olarak ifade edilebilir. Bu sınırlılığı gidermek üzere benzer çalışmalar, nitel veri toplama yöntemlerini de işe katarak planlanabilir. İleri araştırmalarda, bu araştırmada ilk kez incelenen "özel eğitimle ilgili alınan dersler", "mezun olduktan sonra özel eğitim hizmeti veren kurum ya da kuruluşlarda (RAM, resmi veya özel özel eğitim kurumları) çalışma isteği” değişkenleri ile alanyazında hiç incelenmemiş olan "özel gereksinimli bireylerle etkileşimin niteliği” değişkeni sınanabilir.Daha geniş kapsamda yeni araştırmalarda, yeni müfredata tabi olan öğrencilerin, özel eğitimde PDR hizmetlerine ilişkin öz-yeterlik algıları ölçülüp, sonrasında mesleklerini yürütürken bu kişilerin ÖGÖ konusunda performansları ve özel eğitimde öz-yeterlik algılarını ne derecede yordadığı boylamsal çalışmalarla belirlenebilir. 
Rehberlik ve Psikolojik Danışmanlık Programı Öğrencilerinin Özel Eğitimde Öz-Yeterlik Algıları

Rehberlik ve Psikolojik Danışmanlık Programı Öğrencilerinin Özel Ĕ̆itimde Öz-Yeterlik Algıları başlıklı çalışmanın yazım sürecinde bilimsel, etik ve alıntı kurallarına uyulmuş; toplanan veriler üzerinde herhangi bir tahrifat yapılmamış, karşılaşılacak tüm etik ihlallerde "Pamukkale Üniversitesi Eğitim Fakültesi Dergisi Yayın Kurulunun" hiçbir sorumluluğunun olmadığı, tüm sorumluluğun Sorumlu Yazara ait olduğu ve bu çalışmanın herhangi başka bir akademik yayın ortamına değerlendirme için gönderilmemiş olduğunu taahhüt ederim. 


\section{Kaynakça}

Akalın, S. (2014). Okul öncesi eğitim kurumlarında çalışan rehber öğretmenlerin kaynaştırma uygulamalarına ilişkin gereksinimleri. International Journal of Early Childhood Special Education, 6(1), 115-142. https://www.int-jecse.net/index.php/ijecse/article/view/83/74. Erişim tarihi: 24.04.2018

Aksoy, V. ve Diken, İ. H. (2009). Rehber öğretmenlerin özel eğitimde psikolojik danışma ve rehberliğe ilişkin öz-yeterlik algılarının incelenmesi. İlköğretim Online, 8(3), 709-719. https://dergipark.org.tr/download/article-file/90830. Erişim tarihi: 17.01.2018

Altun, F. (2015). Üstün yetenekli öğrencilerin psikolojik danışma ve rehberlik ihtiyaçları, psikolojik danışma yaşantılarl ve rehber ögretmenlerin üstün yeteneklilerle ilgili yeterlik düzeyleri. Yayınlanmamış doktora tezi. Karadeniz Teknik Üniversitesi, Trabzon, Türkiye.

Alver, B. Bozgeyikli H. ve Işıklar, A. (2011). Psikolojik danışma ve rehberlik programı öğrencilerinin kaynaştırma eğitimine yönelik tutumlarının incelenmesi. Atatürk Üniversitesi Sosyal Bilimler Enstitüsü Dergisi, 15(1), 155-168.

Arşit, M. H. (2019). Özel eğitim okulları ile rehberlik ve araştırma merkezlerinde görev yapan rehberlik ögretmenlerinin özel ĕgitimde rehberlik ve psikolojik danışma hizmetlerine ilişkin özyeterliliklerinin incelenmesi. Yayımlanmamış yüksek lisans tezi. Biruni Üniversitesi, İstanbul, Türkiye.

Ateş, M. A. (2017).Rehberlik ve psikolojik danışmanlık bölümü ögretmen adaylarının özel eğitim öz yeterlik algılarının belirlenmesi.Yayınlanmamış yüksek lisans tezi. Yakın Doğu Üniversitesi, Eğitim Bilimleri Enstitüsü, Lefkoşa, K.K.T.C

Balcı, S. (2017). Okul Psikolojik Danışmanı Öz Yetkinlik Ölçeği’nin Türk kültüründeki psikometrik özellikleri. Ahi Evran Üniversitesi Kırşehir Eğitim Fakültesi Dergisi (KEFAD), 18 (2), 633-649.

Bandura, A. (1989). Human agency in social cognitive theory. American Psychologist,44(9), 1175-1184.

Bandura, A. (2009). Cultivate self efficacy for personal and organizational effectiveness. In E. A. Locke (Ed.), Handbook of principles of organizational behavior (2nd ed.), (pp.179-200). New York: Wiley.

Bandura, A. \& Locke, E. (2003). Negative self - efficacy and goal effects revisited. Journal of Applied Psychology, 88(1), 87-99. doi: 10.1037/0021-9010.88.1.87

Cimşir, E. (2019). Özel eğitimde psikolojik danışma ve rehberlik dersinin psikolojik danışman adaylarının engelli öğrencilere ilişkin tutumlarına ve hazırlık düzeylerine etkisi. İlköğretim Online, 18(3),1046-1058. doi:10.17051/ilkonline.2019.610618

Cimşir, E. \& Carney, J. L.V. (2017) School counsellor training, attitudes, and perceptions of preparedness to provide services to students with disabilities in inclusive schools in Turkey. European Journal of Special Needs Education, 32,(3), 346-361, doi: 10.1080/08856257.2016.1240340.

Daniels, J. A. \& Larson, L. M. (2001). The impact of performance feedback on counseling self-efficacy and counseloranxiety. Counselor Education and Supervision, 41(2), 120-130. doi: 10.1002/j.1556-6978.2001.tb01276.x.

Deck, M., Scarborough, J. L., Sferrazza, M. S., \& Estill, D. M. (1999). Serving students with disabilities: Perspectives of three school counselors. Intervention in School and Clinic, 34, 150-155. doi:https://doi.org/10.1177/105345129903400305

Deniz, S. (2016). Rehber öğretmen adaylarının özel eğitime yönelik özyeterlik algılarının incelenmesi. Sosyal ve Beşeri Bilimler Araştırmaları Dergisi, 17(38).154-175.

Fraenkel, J. R., Wallen, N. E. \& Hyun, H. H. (2012). How to design and evaluate research in education (8th ed.). New York: McGraw-Hill. 
Güçyeter, Ş. (2018). Rehber öğretmen adaylarının üstün yetenekli öğrencilerin eğitimleri, sosyal duygusal özellikleri ve rehberlik gereksinimlerine ilişkin farkındalıkları. Milli Eğitim, 1 Özel Sayl,225246.

Gündüz, B. ve Çelikkaleli, Ö. (2009). Okul psikolojik danışmanlarında mesleki yetkinlik inancı. Mersin Üniversitesi Ĕ̈itim Fakültesi Dergisi, 5(1), 119-133.

Gürbüz, S. F. ve Bozgeyikli H. (2014). Rehberlik ve araştırma merkezlerinde çalışan rehber öğretmenlerin özel eğitimde rehberlik ve psikolojik danışmaya yönelik öz-yeterlik algıları. OPUS-Türkiye Sosyal Politika ve Çalışma Hayatı Araştırmaları Dergisi 4(6), 79-99.

Güven, M. (2014). Okullarda rehberlik servisleri-hizmetler. A. Kaya (Ed.). Psikolojik danışma ve rehberlik (s. 55-81) içinde. Ankara: Anı Yayıncılık.

Güven, Y. ve Uyanık Balat, G. (2006). Kaynaştırma uygulamalarına ilişkin rehber öğretmenler ve rehberlik araştırma merkezi çalışanlarının görüşleri. M.Ü. Atatürk Eğitim Fakültesi Eğitim Bilimleri Dergisi,24, 95-108.

Haksı, M. \& Sakalli-Demirok, M. (2016). Evaluating school counselors' self-efficacy perceptions regarding special education. International Journal of Educational Sciences, 15(1-2), 290-303, https://doi.org/10.1080/09751122.2016.11890538. Erişim tarihi: 16.06.2019

Hott, B., Thomas, S., Abbassi, A., Hendricks L. \& Aslina D. (2015). It takes a village: Counselor participation with students, families, and other school personnel in serving students with special needs. National Forum of Special Education Journal,26(1), 1-9. Retrived on May 10, 2018 fromhttp://www.nationalforum.com/Electronic\%20Journal $\% 20$ Volumes/Hott, $\% 20 \mathrm{Brittany} \% 20 \mathrm{It}$ \%20Takes\%20a\%20Village \%20NFSEJ\%20V26\%20N1\%202015.pdf

Johnson, E., Baker, S. B., Kopala, M., Kiselica, M. S., \& Thompson, E. C. (1989). Counseling self efficacy and counseling competence in prepracticum training. Counselor Education and Supervision, 28(3), 205-218. doi:http://dx.doi.org/10.1002/j.1556-6978.1989.tb01109.x

Kaygusuz, C. (2004). Özel eğitim ve rehberlik. A. Kaya (Ed.). Psikolojik danışma ve rehberlik (s.303334) içinde. Ankara: Anı Yayıncılık.

Kayri, M. (2009). Araştırmalarda gruplar arası farkın belirlenmesine yönelik çoklu karşılaştırma (posthoc) teknikleri. Firat Üniversitesi Sosyal Bilimler Dergisi19(1), 51-64.

Kıran, B. ve Dengiz, G. (2019). Okul psikolojik danışmanlarının cinsiyet, deneyim ve öz yeterliklerine göre engelli bireylerin eğitilmesine yönelik tutumlarının incelenmesi. Türk Psikolojik Danışma ve Rehberlik Dergisi, 9(52), 43-67.

Kırbıyık, M. E. (2011). Özel ĕgitim değerlendirme kurulunda görevli rehber öğretmenlerin eğitsel dĕgerlendirme ve tanılama sürecine ilişkin görüşleri. Yayınlanmamış yüksek lisans tezi. Uşak Üniversitesi, Uşak, Türkiye.

Kola, E. (2012). Rehber öğretmenlerin özel ĕgitimde psikolojik danışma ve rehberliğe ilişkin özyeterlik algılarının bazı değişkenler açısından incelenmesi. Yayınlanmamış yüksek lisans tezi. Necmettin Erbakan Üniversitesi, Konya, Türkiye.

Kumcağız, H., Demir, Y., ve Karadaş, C. (2017). Okul psikolojik danışmanlarında mesleki tükenmişliğin yordayıcısı olarak özel eğitime ilişkin öz-yeterlik algısı. Inönü Üniversitesi Eğitim Fakültesi Dergisi, 18(3), 312-324. doi: 10.17679/inuefd.341495.

Milli Eğitim Bakanlığı (2018a). Özel eğitim hizmetleri yönetmeliğihttps://orgm.meb.gov.tr/meb_iys_dosyalar/2018_07/09101900_ozel_egitim_hizmetle ri_yonetmeligi_07072018.pdf Erişim tarihi: 07.10.2018

Milli Eğitim Bakanlığı (2018b). Millı̂ Ĕgitim İstatistikleri Örgün Ĕ̆itim 2017/18. Erişim Adresi: https://sgb.meb.gov.tr/www/resmi-istatistikler/icerik/64Erişim tarihi: 22.04.2018

Milsom, A. S. (2002). Students with disabilities: School counselor involvement and preparation. Professional School Counseling, 5(5), 331-338. Retrived on september 12, 2018 from https://www.jstor.org/stable/42732373 
Nichter, M. \& Edmonson S. L. (2005). Counseling services for special education students. Journal of Professional Counseling: Practice, Theory \& Research, 33(2), 50-62. doi: 10.1080/15566382.2005.12033817

Oberman, A. \& Graham, T. (2016 ). Preparing school counselor trainees to work with students with exceptionalities.[https:/www.counseling.org/docs/default-source/vistas/students-withexceptionalities.pdf?sfvrsn=ef84492c 6] Retrived on september 12, 2018 from VISTAS Online

Özdemir, D. (2018). Rehber öğretmen adaylarının özel eğitime ilişkin öz yetkinlik algıları ve kaynaştırmaya ilişkin görüşlerinin incelenmesi. Yayımlanmamış yüksek lisans tezi. İstanbul Arel Üniversitesi, İstanbul, Türkiye.

Özengi, S. Ş. (2009). Eskişehir ilinde kaynaştırma uygulamalarının yürütüldüğ̈̈ ilköğretim okullarındaki rehber öğretmenlerin kaynaştırmaya ilişkin görüşleri. Yayımlanmamış yüksek lisans tezi. Anadolu Üniversitesi, Eskişehir, Türkiye.

Sakız, H., Woods, C., Sart, H., Erşahin, Z., Aftab, R., Koç, N., et al. (2015). The route to 'inclusive counselling': Counsellors' perceptions of disability inclusion in Turkey. International Journal of Inclusive Education, 19(3), 250- 269. doi: http://dx.doi.org/10.1080/13603116.2014.929186.

Sargın, N. ve Hamurcu, H. (2010). Özel özel eğitim kurumlarında çalışan rehber öğretmenlerin sorunlarına ve beklentilerine yönelik bir çalışma. Selçuk Üniversitesi Sosyal Bilimler Enstitüsü Dergisi, 24, 323-329.

Studer, J. R. \& Quigney, T. A.(2005). The need to integrate more special education content into preservice preparation programs for school counsellors. Guidance \& Counseling, 20(2), 56-83. $\begin{array}{lllll}\text { Retrived on } & \text { Retrived } & \text { on } & \end{array}$ fromhttp://eds.a.ebscohost.com/eds/detail/detail?vid=7\&sid=1 ea77c41-4c9d-4310-b64bbffd92c5a556\%40sessionmgr4007\&bdata=Jmxhbmc9dHImc210ZT11ZHMtbG12ZQ\%3d\%3d\#A $\underline{\mathrm{N}=20096203 \& \mathrm{db}=\mathrm{a} 9 \mathrm{~h}}$

Sütçü, Z. (2007). Yasal düzenlemeler açısından rehber öğretmenlerin/psikolojik danışmanların özel ĕgitimle ilgiligörevlerini uygulamaya yönelik görüşlerinin değerlendirilmesi. Yayımlanmamış yüksek lisans tezi. Selçuk Üniversitesi, Konya, Türkiye.

Tschannen-Moran, M., \& Woolfolk-Hoy, A. (2001). Teacher efficacy: Capturing an elusive construct. Teaching and Teacher Education, 17(7), 783-805. doi: https://doi.org/10.1016/S0742051X(01)00036-1

Urbani, S., Smith, M. R., Maddux, C. D., Smaby, M. H., Torres-Rivera, E., \& Crews, J. (2002). Skillbased training and counseling self-efficacy. Counselor Education and Supervision, 42(2), 92106. doi: 10.1002/j.1556-6978.2002.tb01802.x.

Wood Dunn, N. A., \& Baker, S. B. (2002). Readiness to serve students with disabilities: A survey of elementary school counselors. Professional School Counseling, 5, 277-284.

Vural Batık, M.,\& Fırıncı Kodaz, A. (2018). Kurum deneyiminin psikolojik danışman adaylarının özel eğitim öz yeterlik algılarına etkisi.Ondokuz Mayıs Üniversitesi Ĕgitim Fakültesi Dergisi, 37(1), 209-222. doi: 10.7822/omuefd.327621.

Yılmaz Bingöl, T. (2018). Okul psikolojik danışman adaylarının genel öz-yeterlik ve özel eğitimde rehberlik ve psikolojik danışmanlığa ilişkin öz-yeterlik inançları arasındaki ilişkinin incelenmesi. Uluslararası Toplum Araştırmaları Dergisi, 8(15),1474-1493. doi: 10.26466/opus.444225

Yüksek Öğretim Kurumu (2018). Rehberlik ve psikolojik danışmanlık lisans programı. https://www.yok.gov.tr/Documents/Kurumsal/egitim_ogretim_dairesi/Yeni-OgretmenYetistirme-Lisans-Programlari/Rehberlik ve Psikolojik Danismanlik Lisans Programi.pdf Erişim tarihi: 30.04 .2018

Yüksel, K., Diken, İ. H., Aksoy, V., ve Karaaslan, Ö. (2012). Rehber öğretmen adaylarının özel eğitimde psikolojik danışma ve rehberliğe ilişkin öz-yeterlik algıları. Pamukkale Üniversitesi Ĕgitim Fakültesi Dergisi, 31(1), 137-148. 


\section{Extended Abstract}

\section{Introduction}

School counselors are the first occupational personnel employed in the solution of problems encountered in the execution of special education and support services provided in all institutions and organizations where special education services are provided. However, school counselors find themselves inadequate in fulfilling their duties for the provision of special education services, lack of information and state that they do not receive adequate training in special education (Akalın, 2014; Altun, 2015; Arşit, 2019; Cimşir and Carney, 2016; Güven and Uyanık Balat, 2006; Özengi, 2009; Sakız et al., 2015; Sargın and Hamurcu, 2010; Sütçü, 2007).

The negative experiences experienced by individuals in performing a job may weaken their beliefs that they can do the job, that is, their self-efficacy perceptions (Bandura, 2009). Individuals with low self-efficacy perception may be more reluctant to do the job, avoid difficult tasks, cannot cope with feelings of burnout or failure, and give up quickly, causing him to feel even more inadequate (Tschannen-Moran and Hoy, 2001). It is seen in the studies that self-efficacy perceptions affect the ability of school counselors to have the necessary skills, attitudes and behaviors in order to provide more competent services in special education services. School counselors with low self-efficacy perceptions in special education have low attitudes towards individuals with special needs (Kuran and Dengiz, 2019). It is stated that the level of occupational burnout of school counselors with low self-efficacy perceptions about special education increased (Kumcağız, Demir and Karadaş, 2017). In this case, it can be said that the level of self-efficacy of school counselors in special education services is an important factor in fulfilling their roles in special education services.

In this study, it was aimed to determine the school counselor candidates' perceptions of self-efficacy regarding counseling and guiding services (CaGSs) in special education and the variables that affect these perceptions. The answers to the following questions were sought for this purpose:

1. What is the level of school counselor candidates' perceptions of self-efficacy in special education?

2. Do school counselor candidates' perceptions of self-efficacy in special education differ depending on

a. Gender,

b. Grade level,

c. Taking lessons regarding special education,

d. The period of interaction with the individual (s) with special needs,

e. Whether they want to work in institutions or organizations (Guidance and Research Center, public or private special education institutions) that provide special education services after graduation? 


\section{Method}

The survey model consisted of 243 participants who were volunteers to participate in the guidance and counseling program $(\mathrm{GaCP})$ of two universities. Personal information form and School Counselors' Self-Efficacy Scale regarding Special Education (SCSSSE) were used as data collection tool. Data analysis was analyzed by SPSS 20 package program and t-test for independent groups and ANOVA were used for analysis.

\section{Results}

As a result of the analyzes for the first sub-problem of the study, the average score of the participants was 131.75. Accordingly, school counselor candidates' perceptions of self-efficacy in special education is moderate level.

In the second sub-problem of the research, t-test for independent groups was used to analyze whether there is a significant difference between the scores of the self-efficacy perceptions in special education according to gender. The mean score of women was lower than the mean score of men, but this difference was not significant $(\mathrm{t}(241)=-1.284, \mathrm{p}>.05)$. The ANOVA test was used to determine whether the self-efficacy perceptions of students in special education differed according to grade level. There is a significant difference between the students' perceptions of self-efficacy in special education according to grade level $(\mathrm{F}(2,240)=$ $5,033, \mathrm{p}=.007)$. The results of the post hoc test to find the source of the difference revealed that the difference was caused by the second and third grade participants. According to the results of $\mathrm{t}$ test for independent groups, it was not found significant difference in the mean scores of the candidates who took the learning disability course and did not take it $(t(240)=-, 713, p>$. 05). There was no significant difference between the average scores of the students with the individuals with special needs and those whose duration was less than 1 month and those who had more than 1 month $(\mathrm{t}(241)=-1,261, \mathrm{p}>.05)$. The average score of the students who stated that they want to work in institutions or organizations providing special education services after graduation is higher. The difference between the scores was also significant ( $\mathrm{t}(240)=3.92$, $\mathrm{p}<.01)$.

\section{Discussion}

At the end of the study, the students' perceptions of self-efficacy regarding CaGSs in special education were determined as medium level. These findings, which overlap with other research findings, show the importance of providing adequate training and experience both preservice and in-service in order to increase self-efficacy perceptions of the students in special education. Students' perceptions of self-efficacy in special education did not differ in terms of gender, lessons learned and duration of interaction with the individual(s) with special needs, but significantly differed according to class level and the desire to work in an institution related to special education in the future. At the end of the study together with other research results, the following conclusions can be emphasized and suggestions for further research can be made: It is seen that gender variable is not a variable affecting school counselors' and candidate school counselors' perceptions of self-efficacy in special education. There is a need for studies examining the changes in self-efficacy perceptions in special education according to the courses given to them, according to class level and duration of interaction. 
It is clear that the students attending in the GaCP need more lessons and practices in preservice education in order to increase their self-efficacy perceptions in special education. In this respect, the opening of elective courses related to the special education field in the existing education programs is very essential.

The data obtained from the research are limited to the students attending in the $\mathrm{GaCP}$ of the two universities in the spring semester of 2017-2018, and limited to the measurement tools used to collect the data. In the study, self-efficacy perceptions of the students in special education were measured with a scale and lack of qualitative data for this purpose could be expressed as a limitation. Similar studies to address this limitation can be planned by including qualitative data collection methods. In advanced research, "lessons learned about special education", "willingness to work in institutions or organizations that provide special education services after graduation" and "the nature of the interaction with individuals" can be tested. In a wider scope of new research, the self-efficacy perceptions regarding CaGSs in special education of the students who are taking the new curriculum can be measured and then it can be determined by longitudinal studies how these individuals predict their performance and selfefficacy perceptions in special education. 